\title{
Comparative Techno-Economic Study of Solar Thermal Power Plants with Various Capacities: A Case for the Northern Part of Cameroon
}

\author{
Alain Biboum ${ }^{1, *}\left(\mathbb{D}\right.$, Ahmet Yilanci ${ }^{2}$ (1) \\ ${ }^{1}$ Graduate School of Natural and Applied Sciences, Ege University, Izmir, Turkey \\ ${ }^{2}$ Institute of Solar Energy, Ege University, Izmir, Turkey
}

\begin{abstract}
Cameroon, located in the Sub-Saharan Africa, has a good direct normal irradiation value of about $2145 \mathrm{kWh} /$ $\mathrm{m}^{2} /$ year, but it has a population living with less than $10 \%$ electrification rate in the rural area. The purpose of this study is to evaluate the commercial use of three different solar thermal power technologies (Parabolic trough collector, PTC; Solar Tower, ST; Linear Fresnel, LF) with various capacities (5 MWe, 10 MWe, 50 MWe, $100 \mathrm{MWe}$ ) in the northern part of Cameroon. A techno-economic analysis which uses technical, economic and financial parameters is conducted for each technology, so it is able to give options to investors/designers for evaluating such kind of technologies. In this study, some parameters such as total annual direct normal irradiation (DNI) values received by solar field, thermal output of the solar field, thermal system transfer rate, overall energy efficiency and annual electricity production are considered for the technical analysis. Also, economic and financial results such as payback period (PBP), internal rated return (IRR), net present value (NPV) and levelized cost of electricity (LCOE) are found out during the economic analysis. Moreover, environmental and social impact assessment (ESIA) study is considered as a key parameter for multi-criteria decision analysis. It is obtained that costs per $\mathrm{kW}$ for the solar thermal power plants vary between 4550-6745 USD, 5240-9365 USD and 5100-6290 USD for PTC, ST and LF, respectively. Levelized cost of electricity values are calculated between 10.22-13.22 USDcents/kWh, 11.07-19.81 USDcents/kWh and 14.63-15.60 USDcents/kWh for PTC, ST and LF technologies, respectively. ST technology is not efficient compared to others for less than $10 \mathrm{MWe}$ due to its high initial investment cost. It is important to note that cost per $\mathrm{kW}$ in the sub-Saharan region is high because of high transportation fees, lack of solar thermal manufactures for insulation-piping systems and metal structures, and high indirect costs such as engineering, procurement, construction and advanced ESIA services. Financial support mechanisms for such technologies such as tax exemptions, incentives and subventions based on carbon pricing approach can decrease considerably both payback periods and total costs of the systems, and contribute to developing the sector by creating an attractive solar thermal power market.
\end{abstract}

Keywords: Solar thermal power technologies, concentrating solar energy, techno-economic analysis, financial analysis, economic evaluation.

\section{INTRODUCTION}

Solar thermal power market is supported by developers, financing organizations, manufacturers, engineering-procurement-construction $(\mathrm{EPC})$ companies and institutions that subsidize solar technologies to address global warming issues. This market is mainly based in the European and American continents where the largest industrial or manufactures are able to produce main components of a solar thermal power plant like mirror system, receiver, and piping system etc. Concentrating solar power (CSP) technologies are clas- sified into two groups: The first group is named indirect generating technologies containing parabolic trough collector, solar tower and linear Fresnel, and the second is direct generating technologies containing parabolic dishes and similar technologies under development. The first group concentrates solar radiation and converts it to useful heat with a heat transfer fluid (HTF) or water for a turbine. The other group works with an engine to generate electricity, and the most used engine is Stirling. Some studies used an Ericsson engine instead of a Stirling engine for electricity generation.
* Corresponding authour

Email: biboumalain@gmail.com
European Mechanical Science, March 2020, 4(1): 12-22 doi: https://doi.org/10.26701/ems.493214

Received: December 7, 2018

Accepted: December 17, 2019 
Although the greater support measures initiated by the energy committee of the European Union (EU) in the solar thermal power plant, the global capacity could not exceed $5 \mathrm{GW}_{\mathrm{e}}$ until 2030. For the other existing renewable technologies in power sector, International Renewable Energy Agency's (IRENA) reports predict better values such as 184 GW of PV and $230 \mathrm{GW}$ of wind for the installed capacity by 2030 with a considerable participation of countries in the sub-Saharan region [1-3]. According to recent studies, deployment of CSP technologies is facing face a rapid expansion PV and wind technologies which are also able to meet carbon reduction pledges $[4,5]$. CSPs with storage systems can be used as backup systems for other technologies to supply continuously and constantly the electricity required. Therefore, a rapid expansion of photovoltaic (PV) and wind power plant should open auxiliary market opportunities for CSP technologies since this situation will create a new market for a wider development of storage system for the next generation technologies. Transportation of electricity constraint remains the main challenge for the upcoming decade in these countries because it is the key obstacle for renewable energies standalone technologies due to the intermittent profile of energy supplied to grid utility, which can create serious issues for most countries in the sub-Saharan region.

The economic incentives and subvention from financing institution to invest in CSP are studied in many countries and especially in Africa, where GDP per capita is very low to ensure access to electricity for everyone by reducing the prices of electricity through an affordable levelized cost of energy. Then, to achieve a levelized cost of energy based on the use of renewable energies standalone technologies in general many parameters needs to be adjusted such as, low initial investment including land released, smart procurement and contracting strategy, tax exemption/exoneration for plant equipment, strong know-how in the project development and EPC work. According to a technical report of the renewable power generation costs, the initial investment of CSP project become competitive when the studied scale has to reach 200 MWe capacity for PTC and 100 MWe ST technologies [3]. Morocco's CSP feed-in tariff (FiT) prices have already dropped from 189 USD/MWh for the Noor I project to 140 USD/MWh for Noor II project. The DEWA's CSP project with 700 MWe capacity will be delivered by China's Shanghai Electric at a feed-in tariff price of 73 USD/ MWh [6]. While a solar PV project located at Konya with a capacity of $1 \mathrm{GW}_{\mathrm{e}}$ won by the consortium of Kalyon Enerji and Hanwha Q cells, the generated electricity will be sold at a feed-in-tariff of 69.9 USD/MWh [7]. These last development in the solar energy sector are showing a statement of CSP technologies in the global energy market where developers, industrial and manufacturer are facing new challenges. Some sites can benefit from a range of characteristics such as annual DNI, distance to grid connection and water supply location that help to decrease the cost of electricity. The simulation done by Moore and Apt [8] on the ISCC located in Phoenix Arizona during one year of hourly operations showed that levelized cost of electricity (LCOE) from the solar part of the ISCC varied in the range of 170-380 USD/ MWh. Calise et al. [9] did a dynamic simulation of a polygeneration system using solar-geothermal. In their study, the authors found that LCOE varied between 147.5 Euro/MWh and 172.2 Euro/MWh. Bonyadi et al. [10] studied a solar-geothermal power plant based on the hybridization of an existing geothermal and a solar-powered steam-Rankine. The use of DNI data from Meteonorm Software helped the authors to carry out LCOE for each configuration. According to their results, the range of LCOE was between 163 USD/ MWh and 172 USD/MWh. Techno-economic analysis of a solar thermal power plant was conducted by Beerbaum and Weinrebe [11] to carry out the potential and cost-effectiveness by comparing existing LCOE. The results showed that the cost of centralized CSP system could not exceed 15.8 USDcent/kWh. Silva et al. [12] did thermo-economic design optimization of a parabolic trough solar plant for industrial processes with memetic algorithms. The authors found out LCOE of 5 Eurocent $/ \mathrm{kWh}$. In the way of LCOE adjustment, many suggestions like the increasing of solar multiple (SM), as an example from 1.0 to 2.4, can be considered as a key factor to increase LCOE. The research presented by Boukelia et al. [13] showed that LCOE decreased from 128 USD/ MWh to 86 USD/MWh for CSP-PTC using molten salt as heat transfer fluid and main fluid for thermal energy storage system with 10 hours operating time. Furthermore, the solar field area (solar assembly collectors, power block and storage) can be arranged and manipulated to reduce LCOE. The work conducted by Morin [14] showed a decrease in LCOE from 15.71 USD/MWh to 14.77 USD/MWh (6.0\%). A study conducted by Nezammahalleh et al. [15] based on the use of Direct steam generation (DSG) system in the solar thermal power plant compared to the use of ISG system in order to demonstrate the competitiveness and effectiveness of using water. In the study, the authors showed that decreases of initial investment and operation-maintenance (O\&M) costs impacted on LCOE. Musi et al. [16] presented a techno-economic analysis of CSP by calculating LCOE. In their study, they found that the level of technical knowledge and maturity, developments in the sector of manufacturing, industry, and existing STTP had a considerable effect on LCOE. Furthermore, the analysis revealed that plant with the highest capacity factor and thermal energy storage (TES) had the lowest LCOE. In term of technology, linear Fresnel technology presented the lowest LCOE compared to the others. Kost et al. [17] did an economic assessment of CSP technologies based on LCOE considering electricity market conditions. The study demonstrated that LCOE analysis neglected a positive impact of thermal energy storage on the electricity price. In a study by Del Rio et al. [18], it was mentioned that uncertain, retroactive and insufficient policies related to good and clean productions were the most important barriers related to the high cost of CSP technology compared to other renewable and conventional power technologies. Lipu and Jamal [19] did a techno-economic analysis of a solar 
thermal power plant in Bangladesh using data of the solar projects, Andosol-1 and PS10, as references. This analysis was conducted to carry out specific technical and financial data for the use of CSP technologies to produce electricity. The authors proposed to set an integrated energy planning approach for Bangladesh government able to consider barriers for the sustainable development of concentrating solar power technologies.

\section{CONTEXT AND CASE STUDY}

\subsection{Context}

The solar thermal power technologies in Africa can benefit some funds from different financial institutions like World Bank, AfrEximBank, African Development Bank, and from organizations related to these institutions such as Climate Investment Funds (CIF), Clean Technology Fund (CTF) through some agreement with national authorities of energy regulatory agency (ERA) [20]. To obtain those kinds of funds, local ERA has to process through an accreditation process of different type of certificate from Green Climate Fund (GDF), Global Clean Development Mechanism (GCDM) etc. [21,22]. These funds contribute to reducing LCOE considerably for CSP projects. For example, according to ACWA Power, a concessional fund from financing institutions has been attributed to Noor I's project in Morocco in order to reduce LCOE to a three quarter [1], A good negotiation of carbon bonus named CER/TAX in this study can contribute to promoting the use of the CSP technology instead of a coal-fired power plant in some sub-Saharan region like Niger where an important potential of solar irradiation and coal are available. This energy policy has been applied in South-Africa republic, where CSP is becoming a common technology. Due to that, the aim of this study consists to promote the implementation of new energy policies including thermal power plant using renewable energy resources taking into account global incentives in partnership with institution and organization to prevent pollution. Hybrid projects using CSP as a backup system is one of the most recent perspectives in different studies in sub-Sahara research centers. Burkina Faso has already developed a small size scale to evaluate the potential of its use. Morocco Agency for Sustainable Energy (MASEN) has requested proposals for two hybrid solar PV-CSP power plants containing storage system at Noor Midelt. The sizes of the proposed projects are 150 MWe and 190 MWe, respectively. MASEN predicts lower prices of Feed-in-Tariff than current operating stand-alone CSP project at Noor Ouarzazate The last developments of CSP projects in Morocco have created an attractive labor market of the renewable energies for the local population through a delocalization of some foreign manufacture branch contributing in fact in the energy sector development by employment. Nevertheless the replacement of some jobs by automation of manufacturing facilities, the scope of Research and Development (R\&D) continue to increase which may lead to further demands in some resear- ch center [21-24]. According to this situation, countries of sub-Saharan have to adjust the main research topic to future needs in the area such as project development, design, control, and inspection. Existing literature categorizes renewable energy employment in the CSP sector according to the value chain and the skill level requirement.

The direct employment of such kind of project is resulting from project design and ESIA studies and EPC works like construction, installation, and maintenance. The indirect employment is related to manufacturing and supply of equipment, materials, services for the plant facility and other services provided by the organizations, financial institution and banking sectors to the owner of the facility. The indirect services can contribute more to employment when the countries have an important total capacity installed. To ensure a sustainable development in this sector, it is very important to follow the evolution of the market in Western countries.

\subsection{Case Study}

Cameroon plans to mix the use of energy produced by using renewable energy resources. According to the electricity sector regulation agency (ARSEL), the national electricity production can be divided among different natural resources such as hydro, biomass, solar, wind, and other resources used for thermal installation as fossil resources (fossil fuels, natural gas and coal).

In order to contribute to increasing of alternative for Cameroon energy mix target, this study presents a solution using CSPs to meet energy demands and industrial purposes. The methodology of this study focuses on the development of solar thermal power plants in the sub-Saharan countries like Cameroon. To achieve this objective, Multi-Criteria Decision Maker (MCDM) method is used to identify potential sites for a solar thermal power plant in the northern region of Cameroon. The following towns have been selected: Diamere, Logone and Chari, Mayo Danay and Mayo Sava. The main difficulties in the site selection are classified as factors containing several sub criteria such as access to grid connection and road, annual direct normal irradiation (DNI), wind speed and other characteristics. The distance between the site of the studied plant and the main road is one of the most important sub-criteria because is related to cost and losses of the transmission line, water conduit. The terrain slope will be associated with the local meteorological conditions to optimize the generated electricity as sub-criteria of the geographical factor. Given the growth in energy demand over the years, it is important to note that the migratory flows in the far north represent a quarter of its population due to Nigerian and Central African Republic conflicts.

\section{DESCRIPTION AND METHODOLOGY}

\subsection{Site selection}

This study uses Analytic Hierarchy method (AHP) for the identification of the suitable site using various sub criteria in 
order to develop CSPs. A techno-economic analysis is conducted for the comparative evaluation of the CSPs.

The sub-criteria and the main criteria used during the AHP method will be treated with more detail in the following se- ction to show the simplicity and the final aims of our work. To classify solar technology used for solar thermal power plant construction compatible with the selected site and the expected size of plant; many considerations are taken into

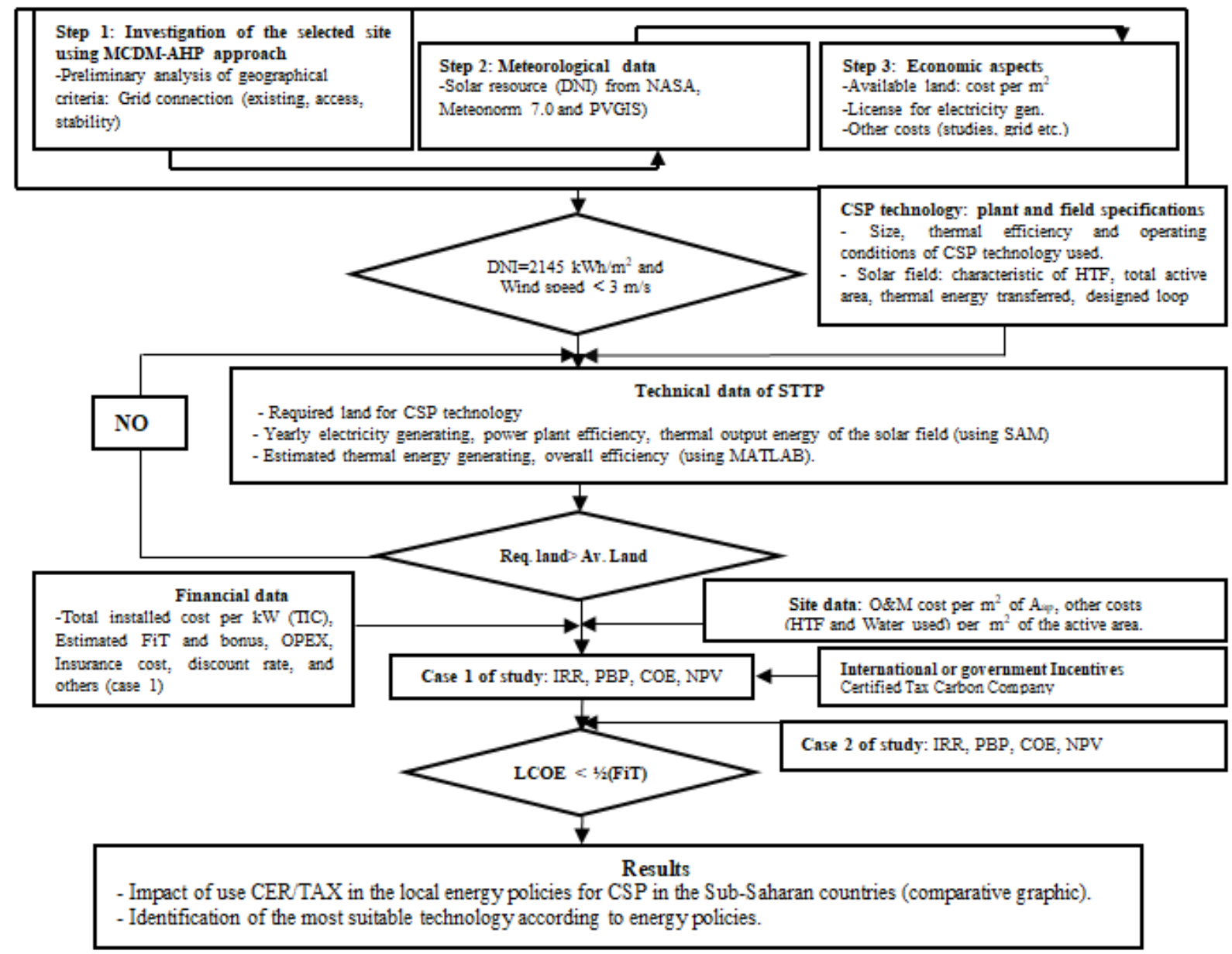

Figure 1. Methodology of the selection of the site and the technologies.

Table 1. Factors and criteria used in MCDM method for the selection of the site [25].

\begin{tabular}{|c|c|c|c|c|c|c|c|c|}
\hline Criteria & $\begin{array}{c}\text { Consistency Eigenvalues, } \\
\text { and Weight }\end{array}$ & Sub-criteria and Weight (\%) & $\begin{array}{l}\text { FARO } \\
\text { Poli }\end{array}$ & $\begin{array}{l}\text { FARO } \\
\text { Bouki }\end{array}$ & VAIMBA & $\begin{array}{l}\text { BENUE } \\
\text { Tchebo }\end{array}$ & $\begin{array}{l}\text { BENUE } \\
\text { Toroua }\end{array}$ & $\begin{array}{l}\text { BENUE } \\
\text { Adoumre }\end{array}$ \\
\hline \multirow[t]{4}{*}{ Geographical } & CR: 0.00079 & Access to raw material (ARM)- 16.2 & 0.7 & 0.85 & 1 & 1 & 1 & 1 \\
\hline & $\mathrm{Cl}: 0.00071$ & Direct normal irradiation(DNI)- 40.5 & 0.99 & 0.996 & 0.995 & 0.996 & 0.974 & 1 \\
\hline & $\Lambda: 4.002$ & Wind speed (WS)- 16.2 & 1 & 1 & 00.96 & 1 & 0.93 & 0.91 \\
\hline & & Stability \& access to the grid (SAG)-27.1 & 1 & 1 & 0.6 & 0.8 & 0.8 & 1 \\
\hline & & W: $31.25 \%$ & $29.7 \%$ & $30.5 \%$ & $27.3 \%$ & $29.5 \%$ & $28.5 \%$ & $30.1 \%$ \\
\hline \multirow[t]{3}{*}{ Economical } & CR: 0.32 & Land cost (LC)-30.7 & 0.7 & 0.8 & 1 & 1 & 1 & 1 \\
\hline & Cl: 0.0017 & Fees for grid connection (FGC)- 46.2 & 1 & 1 & 0.6 & 0.7 & 0.7 & 0.8 \\
\hline & $\Lambda: 3.003$ & Project development cost (IPD)- 23.1 & 1 & 1 & 0.9 & 0.6 & 0.6 & 0.6 \\
\hline \multicolumn{3}{|r|}{ W: $18.75 \%$} & $17.0 \%$ & $17.6 \%$ & $14.8 \%$ & $14.4 \%$ & $14.4 \%$ & $15.3 \%$ \\
\hline \multirow[t]{4}{*}{ Social } & CR: 0.0002 & E. access to land/water (EALW)-26.8 & 1 & 0.9 & 0.6 & 0.8 & 0.8 & 0.9 \\
\hline & Cl: 0.001 & Communities attitudes (CA)-35.7 & 1 & 1 & 1 & 1 & 1 & 1 \\
\hline & $\Lambda: 3.002$ & External factor- safety (EFS) - 35.7 & 1 & 1 & 0.6 & 0.6 & 0.8 & 0.4 \\
\hline & \multicolumn{2}{|r|}{$W: 27.08 \%$} & $2.6 .7 \%$ & $25.6 \%$ & $19.9 \%$ & $23.3 \%$ & $23.3 \%$ & $20.14 \%$ \\
\hline \multirow[t]{5}{*}{ Environmental } & CR: 0.0038 & Wildlife protection cost (CWLP)-29.8 & 1 & 0.9 & 0.9 & 0.8 & 0.8 & 0.8 \\
\hline & $\mathrm{Cl}: 0.020$ & Effect of pollution (EP)-30.2 & 0.4 & 0.6 & 1 & 0.9 & 0.9 & 0.8 \\
\hline & $\Lambda: 3.004$ & Infrast. development level (IDL)-40 & 1 & 0.7 & 0.5 & 0.7 & 0.7 & 0.8 \\
\hline & \multirow{2}{*}{\multicolumn{2}{|c|}{ W: $19.92 \%$}} & $24.5 \%$ & $21.8 \%$ & $23.0 \%$ & $23.6 \%$ & $23.6 \%$ & $23.9 \%$ \\
\hline & & & $97.9 \%$ & $95.5 \%$ & $85.0 \%$ & $90.8 \%$ & $89.8 \%$ & $89.4 \%$ \\
\hline
\end{tabular}


Table 2. Main specifications of the solar fields based on solar thermal conversion technologies.

\begin{tabular}{|c|c|c|c|c|c|c|c|}
\hline \multicolumn{8}{|c|}{ CSP - PTC: Loop design for PTC technology for 50 MWe (SM: 2.00) } \\
\hline & operating temp.(C) & flow rate $(\mathrm{kg} / \mathrm{s})$ & $\begin{array}{l}\text { flow velocity } \\
\qquad(\mathrm{m} / \mathrm{s})\end{array}$ & $\begin{array}{l}\text { Aperture } \\
\left(\mathrm{m}^{2}\right)\end{array}$ & Optical efficiency & \multicolumn{2}{|c|}{ Conversion efficiency } \\
\hline Min & 293 & 1 & 0.2685 & & \multirow{2}{*}{0.7405} & \multirow{2}{*}{\multicolumn{2}{|c|}{0.7082}} \\
\hline Max & 391 & 12 & 3.744 & & & & \\
\hline \multicolumn{8}{|c|}{ CSP - ST: Specifications of heliostat and receiver used for simulation (SAM Software) } \\
\hline \multicolumn{2}{|c|}{ specifications of Heliostat } & \multicolumn{2}{|c|}{ Tower and receiver specifications } & \multicolumn{2}{|c|}{ specifications of Heliostat } & \multicolumn{2}{|c|}{ Tower and receiver specifications } \\
\hline \multicolumn{2}{|c|}{ Heliostat Width (m) } & \multicolumn{2}{|l|}{12.2} & \multicolumn{2}{|c|}{ Heliostat Width (m) } & \multicolumn{2}{|l|}{12.2} \\
\hline \multicolumn{2}{|c|}{ Heliostat Height (m) } & \multicolumn{2}{|l|}{12.2} & \multicolumn{2}{|c|}{ Heliostat Height (m) } & \multicolumn{2}{|l|}{12.2} \\
\hline \multicolumn{2}{|c|}{ The ratio of reflective area to profile } & \multicolumn{2}{|l|}{0.94} & \multicolumn{2}{|c|}{ The ratio of reflective area to profile } & \multicolumn{2}{|l|}{0.94} \\
\hline \multicolumn{2}{|c|}{ Single heliostat area $\left(\mathrm{m}^{2}\right)$} & \multicolumn{2}{|l|}{140} & \multicolumn{2}{|c|}{ Single heliostat area $\left(\mathrm{m}^{2}\right)$} & \multicolumn{2}{|l|}{140} \\
\hline \multicolumn{2}{|c|}{ Reflected image conical error } & \multicolumn{2}{|l|}{$4.327 \mathrm{mrad}$} & \multicolumn{2}{|c|}{ Reflected image conical error } & \multicolumn{2}{|l|}{$4.327 \mathrm{mrad}$} \\
\hline \multicolumn{2}{|c|}{ Number of heliostat facets- $X$} & \multicolumn{2}{|l|}{2} & Number of helio & stat facets-X & 2 & \\
\hline Numb & f heliostat facets-Y & 8 & & Number of helio & stat facets-Y & 8 & \\
\hline CSP - S & Specification of solar field & used for Solar Towe & er power plant for & 100 MWe (SM: 2 & .00) & & \\
\hline & Operating temp. & $\begin{array}{l}\text { Ratio height Heli- } \\
\text { ostat7Tower. }\end{array}$ & $\begin{array}{l}\text { Distance }(\mathrm{m}) \\
\text { Heliostat7Tower }\end{array}$ & $\begin{array}{c}\text { Aperture area } \\
\left(\mathrm{m}^{2}\right)\end{array}$ & Syst. Cap. & $\begin{array}{l}\text { Tower height } \\
\text { Receiver height }\end{array}$ & $\begin{array}{l}\text { Receiver dia. } \\
\text { Nb. of panels }\end{array}$ \\
\hline Min & $290^{\circ} \mathrm{C}$ & 9.5 & 131.216 & 139.95 & $100 \mathrm{MWe}$ & 174.95 & 17.35 \\
\hline Max & $574^{\circ} \mathrm{C}$ & 0.75 & 1662.07 & 1216500.00 & & 20.95 & 20 \\
\hline CSP - 1 & Specifications of collector & and receiver used $f$ & for simulation (SA & AM Software) & & & \\
\hline & specification & of Collector & & & Receiver & pecifications & \\
\hline Reflect & area of the collector $\left(\mathrm{m}^{2}\right)$ & 470 & & Absorber tube ir & nner diameter $(m)$ & & 0.066 \\
\hline Length & collector module (m) & 44 & & Absorber tube o & uter diameter (m) & & 0.07 \\
\hline $\begin{array}{l}\text { Length } \\
\text { (m) }\end{array}$ & crossover piping in a loop & 15 & & Glass envelope i & nner diameter $(m)$ & & 0.115 \\
\hline The pi & distance between module $(\mathrm{m})$ & 1 & & Glass envelope c & juter diameter $(\mathrm{m})$ & & 0.12 \\
\hline Mirror & lectivity & 0.9 & & Internal surface & roughness & & t. 5 - -005 \\
\hline Numb & ollector module per loop & 16 & & Absorber mater & al type & & 2 cooper \\
\hline CSP - I & pecification of solar field & used for Linear-Fres & snel power plant $f$ & or $50 \mathrm{MWe}$ (SM: & 1.25) & & \\
\hline & Operating temp. & $\begin{array}{l}\text { Mass flow rate } \\
\text { per loop }(\mathrm{kg} / \mathrm{s})\end{array}$ & $\begin{array}{l}\text { Velocity of HTF } \\
\qquad(\mathrm{m} / \mathrm{s})\end{array}$ & $\begin{array}{l}\text { Loop optical } \\
\text { eff. }\end{array}$ & $\begin{array}{c}\text { Syst. Cap. } \\
\text { (Solar Multiple) }\end{array}$ & $\begin{array}{l}\text { Land aperture } \\
\text { Total land }\left(\mathrm{m}^{2}\right)\end{array}$ & $\begin{array}{c}\text { D. Area of loop } \\
\text { (Number of the loop) }\end{array}$ \\
\hline Min & $293^{\circ} \mathrm{C}$ & 3.01 & 2 & $0.611-0.595$ & $50 \mathrm{MWe}$ & 993300 & 7524.8 \\
\hline $\operatorname{Max}$ & $525^{\circ} \mathrm{C}$ & 14.47 & 3 & & $(1.25)$ & (1590 000) & (132) \\
\hline
\end{tabular}

account. The combined method using AHP method and techno-economic evaluation consists to set an optimal procedure able to analyze the most suitable combination between a solar plant characteristic and site location.

AHP method structures the analysis in hierarchical levels by using sub-criteria, criteria and many levels necessary for a suitable determination. After the identification of the problem, weight evaluation of the criteria and sub-criteria pairs, these locations can be compared to determine the best size of project according to the available resources and CSP technologies type as shown in Figure 1.

For the site selection in the province of Garoua, multi-criteria decision making (MCDM) method has been chosen among other methods. AHP is one of the common approaches used for the determination of site location and solar power project evaluation $[25,26]$. The conventional AHP method used in the study has a particularity to wise comparison for each level with respect to the best goal, to carry out the best site. In AHP method, the main criterion and sub-criteria of each factor should be well defined. Main and sub-criteria can be obtained in literature, governmental report, an investigation on the ground. Consistency ratio (CR) can be estimated using the consistency index (CI). The appropriated sites in the north provinces of Cameroon are specified with various criteria shown in Table 1. This table presents the importance of each criterion and sub-criteria used for AHP method by evaluating their weight taken into account during the simulation. The level-headed sub criteria vary according to the site location and others specific considerations.

\subsection{CSP technologies}

Parabolic trough collector (PTC) consists of many module assemblies supported by a metallic structure. The collector concentrates incoming sunlight into an absorber linear tube considered as a focal line. The length of the mirror per loop depends essentially to the size and number of module used. The module specifications in this study are presented in Table 2. The tracking system orients collector toward the solar by using a single axis technology in order to optimize the electricity generation. Loops are usually configured along North-South direction, and tracking system allows the collectors to move from East to West.

Linear Fresnel (LF) reflectors have many similarities with PTC technology due to loop constitution and focal line utilization to concentrate sunlight. LF technology uses flat or slightly curved mirror placed at a different angle to concentrate sunlight to a linear tube located in a fixed position. Each line of the mirror is equipped with a single axis tracking system. The technical specifications and design of the receiver 
are almost the same as the one used for PTC technology.

Solar Tower (ST) technology consists of assemblies of a number of small computer-controlled mirrors called heliostats. The ground mounted-based field is fixed and the heliostat on top of each pillar focuses the direct irradiation onto the central receiver mounted higher on a tower. To optimize the electricity generation, each heliostat tracks the sun individually using a two-axis tracking system.

The towns in the province of Garoua have a direct normal irradiation around $2145 \mathrm{kWh} / \mathrm{m}^{2}$. Five towns have been selected with almost same potential considering geographical criteria. Therminol VP-1 has been selected during the simulation as a heat transfer fluid (HTF) for PTC technology, assembled by Luz LS2 and Schott PTR80 as receiver and absorber respectively. Solar multiple (SM) value is selected as 2.0 for the thermal plant with a capacity equal or more than 50 MWe. Main specific data of the designed loop can be found in Table 2 . The molten salt chemically named $60 \% \mathrm{NaNO}_{3} 40 \% \mathrm{KNO}_{3}$ is the HTF used to simulate thermal plant using ST technology. The solar field contains heliostats in the $\mathrm{T}$ geometry and each one has 16 facets with $140 \mathrm{~m}^{2}$ as a total area. Technical data of used heliostat are presented in Table 2. During the simulation, the main aim is to optimize annual energy produced by the power plant. The molten salt is used as HTF for a thermal power plant using LF technology. Using this technology, some data have been found for solar field configuration. The analysis is conducted to carry out characteristic of the designed loop, a piping distance between the sequential module and the number of modules per SCA presented in the table above. The solar multiple for LF technology with a size bigger than 50 MWe is 1.25 , and

Table 3. Equations and assumptions used in the technical assessment. Equations

\begin{tabular}{|c|c|}
\hline Equations & Assumptions \\
\hline $\begin{array}{l}\text { The annual DNI received by the solar field aperture area: } \\
\qquad E P_{S F}=Y . D N I \times \text { Solar Field aperture area }\end{array}$ & $\begin{array}{l}\text { It depends on the DNI of the plant location }\left(2145 \mathrm{kWh} / \mathrm{m}^{2}\right) \text { and the area of } \\
\text { the plant according to and the CSP technology used during construction } \\
\text { (SAM). }\end{array}$ \\
\hline $\begin{array}{l}\text { The solar field efficiency: } \\
\qquad \eta_{S F}=\frac{\text { Solar Field apertur earea }}{\text { Site area }}\end{array}$ & $\begin{array}{l}\text { The solar field efficiency is the main data use during ESIA and feasibility stu- } \\
\text { dies to optimize the use of an available natural resource like water, land etc... } \\
\text { This ratio has to be above } 0.3 \text {. }\end{array}$ \\
\hline $\begin{array}{l}\text { The power plant production efficiency: } \\
\qquad \eta_{\text {STPP }}=\frac{\text { Annual Electricity Production }(\text { GWhe })}{\text { Yearly thermal energy produced by aperture Solar field }(\text { GWht })}\end{array}$ & \multirow{2}{*}{$\begin{array}{l}\text { The power plant production and overall efficiency are key values in develo- } \\
\text { ping countries with high demography. Despite the necessity to use renewable } \\
\text { it also important to optimize production. Then, we assumed that and have } \\
\text { to be respectively above to : } \\
\qquad \begin{array}{l}12 \% \text { and } 13.5 \% \text { for CSP - PTC technology } \\
10 \% \text { and } 18.5 \% \text { for CSP - ST technology } \\
10 \% \text { and } 26.1 \% \text { for CSP - LT technology }\end{array}\end{array}$} \\
\hline $\begin{array}{l}\text { The overall efficiency of a studied thermal system: } \\
\qquad \psi_{\text {STPP }}=\frac{\text { System capacity }(M W e)}{\text { Solar Field Thermal output }(M W t)}\end{array}$ & \\
\hline $\begin{array}{l}\text { The estimated thermal energy production of the studied system: } \\
\qquad T E P_{\text {STPP }}=\text { Annual Electricity Production }(\text { GWhe }) \times \frac{1}{\psi_{\text {STPP }}}\end{array}$ & \multirow{2}{*}{$\begin{array}{l}\text { Thermal energy produced by the system depends on the type of CSP techno- } \\
\text { logy used. }\end{array}$} \\
\hline $\begin{array}{l}\text { The thermal efficiency of a solar field: } \\
\qquad \eta_{t h-S F}=\frac{T E P_{S T P P}}{\text { Annual DNI received by thesolar field apertur earea }}\end{array}$ & \\
\hline $\begin{array}{l}\text { The thermal energy transferred by the solar power plant: } \\
\qquad T E T_{\text {STPP }}=\frac{\text { Solar Field Thermal Output }(M W t)}{\text { Annual DNI received by thesolar field aperture area }}\end{array}$ & $\begin{array}{l}\text { The thermal energy transferred rate has to exceed } \\
30 \% \text { for CSP-PTC technology, } 50 \% \text { for CSP-ST technology, } 55 \% \text { for } \\
\text { CSP-LT technology }\end{array}$ \\
\hline $\begin{array}{l}\text { The performance factor: } \\
\qquad \eta=\frac{\text { Annual Electricity Production per installed Watt }}{\text { Utilized solar resource }}\end{array}$ & \multirow[t]{2}{*}{$\begin{array}{l}\text { The capacity factor is the main value used by experts to evaluate the hybridi- } \\
\text { zation option of the installed plant. }\end{array}$} \\
\hline $\begin{array}{l}\text { The capacity factor: } \\
\qquad C F=\frac{\text { Annual electricity produced) }}{\text { Nameplate } \times 24 \times 365}\end{array}$ & \\
\hline
\end{tabular}

land use and water consumption are very low compared to other technologies. The solar field preparation for plant simulation has been taken into account according to the technology used. Thermal output, solar field aperture area, land area, annual electricity production and mass flow rate of the heat transfer fluid have been found in the simulation. Others technical parameters like Annual DNI received by the solar field aperture area, overall efficiency, power plant production efficiency, estimated thermal energy production, thermal efficiency and thermal energy transferred are calculated using the Matlab software.

\subsection{Techno-economic analysis}

Techno-economic analyses of the studied solar thermal power plants consider all used parameters during the site selection and the technical analysis plus financing data in order to optimize LCOE. Table 3 shows the equations and assumptions used in the technical analysis. Annual O\&M cost is estimated between $1.5 \%$ and $2.5 \%$ of the direct initial investment of the project according to the type of CSP technology $[4,5,27]$. In 2010, the energy technology perspective reports revealed that it was necessary to choose a conservation value of discount rate according to the practical reality of the project location. Therefore, in this study, discount rate is selected to be $7 \%$ for any technology independently of the project size $[20,21,25]$. As mentioned before, the agency suggests insurance cost in the range between $0.5 \%-1 \%$ of the total income per year. Therefore, in this study, value of insurance cost is assumed to be $0.5 \%$. The specific land cost of the studied location is estimated to be $1.50 \mathrm{USD} / \mathrm{m}^{2}$ for 30 years project lifetime with annual degradation factor of $1 \%$. The total installation cost of the solar thermal power It depends on the DNI of the plant location $\left(2145 \mathrm{kWh} / \mathrm{m}^{2}\right)$ and the area of the plant according to and the CSP technology used during construction

The solar field efficiency is the main data use during ESIA and feasibility stu-

The power plant production and overall efficiency are key values in developing countries with high demography. Despite the necessity to use renewable it also important to optimize production. Then, we assumed that and have $0 \%$ and $26.1 \%$ for CSP - LT technology 
Table 4. Equations and assumptions used in the techno-economic analysis [25,27].

\begin{tabular}{|c|c|}
\hline Equations & Assumptions \\
\hline $\begin{array}{l}\qquad E_{i}=E_{0}\left(100-\frac{D R}{100}\right)^{i} \\
\text { DR: Degration factor. } \\
E_{0}: \text { Electricity produced at the beginning }\end{array}$ & $\begin{array}{l}\text { The annual electricity produced by the STPP depends only on the CSP } \\
\text { technology en parametric values of the main component used before the } \\
\text { commissioning of the plant. }\end{array}$ \\
\hline Gross Profit $=$ Discounted Cash flow + Discounted Residual value & \multirow{2}{*}{$\begin{array}{l}\text { The weight average cost of capital can be calculated using proportionate } \\
\text { interest and equity rates by the best: } \\
\text { But in our case study, we assumed that the owner of the solar power plant } \\
\text { didn't get any debt from financing institution. } \\
\text { Real FiT : } 27 \text { USD Cents/kWh - less than } 10 \mathrm{MWe} \\
\text { Real FiT : } 21 \text { USD Cents/kWh - between } 10.1-100 \mathrm{MWe}\end{array}$} \\
\hline $\begin{array}{l}\text { Discounted Cash flow }=\left(\frac{\text { RealFiT }+ \text { Bonus }}{\delta^{n}}\right) \times A E P \times\left(1-\frac{1}{(1+\delta)^{n}}\right) \\
\text { Discounted Cash flow }=(\text { RealFiT }+ \text { Bonus }) \times A E P \\
\quad \text { Bonus : } 3 \text { USD Cents } / \mathrm{kWh}\end{array}$ & \\
\hline Discounted Residual Value $=$ Real installed cost $*$ Residual Value $\%$ & $\begin{array}{l}\text { The residual value is not taking account in this case study because there is no } \\
\text { interaction with the financing institution. }\end{array}$ \\
\hline $\begin{array}{l}\boldsymbol{E B I T}=(\text { Gross Profit }- \text { Discounted OPEX }) \\
E A I T=E B I T+\text { Discounted } C E R / T A X \\
\text { Discounted } C E R T A X=A E P\left(M W_{e}\right) \times 7.1 t C O_{2} \times 4.397\end{array}$ & \multirow{2}{*}{$\begin{array}{l}\text { Gross profit margin is calculated by deducting the cost of goods sold } \\
\text { (electricity generation cost) from the revenue generated by the sale of the } \\
\text { energy produced. The earnings before interest and tax (EBIT) are calculated } \\
\text { by deducting the operating cost from the gross production. After interest } \\
\text { and tax (EAIT) are calculated by adding related to the possibility to sell } \mathrm{CO}_{2} \\
\text { to environmental institutions or a Coal power plant owner ( } 1 \mathrm{MWh} \text { per } 7.14 \\
\mathrm{tCO}_{2} \text { and } 1 \mathrm{t} \mathrm{CO}_{2}-4.4 \text { USD) using a CER/TAX. The EAIT had been used in the } \\
\text { techno-economic analysis to determinate abatement of the payback period. } \\
\text { The value of ROI is one of the best indicators for the investor. }\end{array}$} \\
\hline$R O I=\left(\frac{\sum_{i=1}^{n} \frac{E B I T}{(1+r)^{i}}}{\text { Real installed cost }}-1\right)$ & \\
\hline$N P V=-$ Real installed cost $+\sum_{i=1}^{n} \frac{E B I T_{i}}{(1+r)^{i}}$ & $\begin{array}{l}\text { As explained above, the next present value is a very good indicator and has to } \\
\text { be a positive value for a bankable project. }\end{array}$ \\
\hline Real installed cost $=\sum_{i=1}^{n} \frac{E B I T_{i}}{(1+I R R)^{i}}$ & $\begin{array}{l}\text { In our case study, we used } 7 \% \text { as discount rate value and we assumed that: } \\
\text { a solar thermal project became full bankable when the IRR is more than } 11 \% \\
\text { due to some inconvenient related to this new market (Insurance, Inspection, } \\
\text { PPA negotiation related to inflation in the countries etc.) }\end{array}$ \\
\hline$L C O E_{i}=\frac{\text { Real discount cost }(1+\text { OMcost }+ \text { TIRcost }+ \text { AMRcost })}{(\text { Annual Energy generated })_{m e}}$ & $\begin{array}{l}\text { The calculation of LCOE was our main goal in order to carry out the Real FiT } \\
\text { value for Solar thermal power plant independently to CSP technology. We } \\
\text { assumed that in the beginning maximum value of LCOE calculated can't be } \\
\text { under the half of real FiT fixed. }\end{array}$ \\
\hline
\end{tabular}

plant takes into account the direct and indirect cost such as project development, permits, and land cost. In this study, there are not financing and real installation cost assumption, then the total real installation cost is not considered. FiT price is estimated based on type of used technology, initial investment and support from the financing institution 'carbon pricing approach'. FiT prices as 27 USDcent $/ \mathrm{kWh}$ and 21 USDcent $/ \mathrm{kWh}$ are assumed without any bonus of solar thermal power plants with a capacity less than 10.0 MWe and more than $10.1 \mathrm{MWe}$, respectively. To carry out its value, the equations presented in Table 4 are used by taking into consideration some key parameters, most of which are from the technical reports $[3-5,7,21,22]$.

\section{RESULTS AND DISCUSSION}

Sites in Faro location present many advantages for a solar project with a priority order of $98-95 \%$ compared to other selected locations for this study. These sites are suitable for stability, fees and access to grid connection, security, and access to water. Among all selected locations, Vaimba presents $85 \%$ as a priority order which is the worst performance compared to other sites. However, it remains the best location for hybridization with a biomass power plant.

Table 5 shows the main technical and economic data used in the techno-economic analysis and obtained results of the analysis.

\subsection{Technical analysis}

The implementation of CSP projects in the northern part of Cameroon can be done since it owns a high DNI estimated at $2145 \mathrm{kWh} /$ year $/ \mathrm{m}^{2}$. Their environmental and social impact assessment is essentially based on the use of available resources such as active area of the solar field. The effectiveness of the solar field can be estimated through the sustainability of the project and its respect for the environment. For this purpose, the power projects based on ST or PTC technology have a ratio equal to $41.6 \%$ while the ratio of solar projects based on the LF technology has a ratio of $62.5 \%$ which makes it an environmental friendly technology. In addition, annual energy production per unit area fluctuates between $191.70 \mathrm{kWh} / \mathrm{m}^{2}$ and $317.97 \mathrm{kWh} / \mathrm{m}^{2}$ for the solar thermal power plants of 10 MWe capacity using ST and PTC technologies, respectively. Based on these results, LF technology responds well to the environmental conditions compared to other CSP technologies used in the projects simulation as shown in Figure 2.

The overall efficiency values of the solar thermal power plants are calculated for each size, and they are found to be $11.58 \%$ for $5 \mathrm{MWe}-\mathrm{PTC}$ as a lower efficiency system, and $28.37 \%$ for $100 \mathrm{MWe}-\mathrm{LF}$ as the best value. In terms of power plant production efficiency, the highest value is calculated to be $12.38 \%$ for $5 \mathrm{MWe}-\mathrm{PTC}$. Furthermore, this plant has 


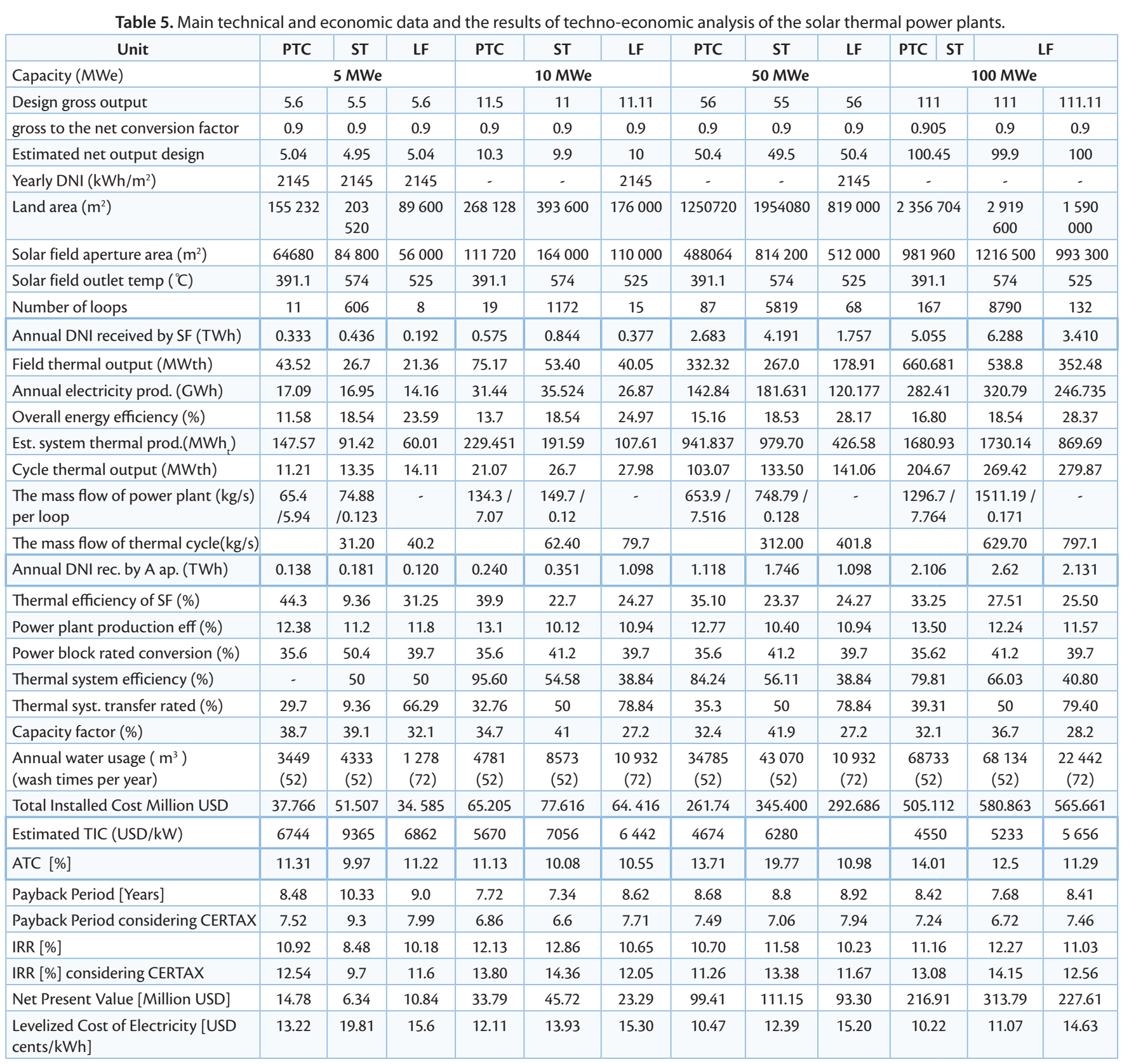

also the highest value thermal efficiency of about $44.3 \%$. But the heat transfer rate is above $66.2 \%$ for LF technology. The location of the solar field has to be chosen carefully in order to avoid a high consumption of water for cleaning issue. Our study reveals that CSP using LF technology needs to be clean more than other technologies. O\&M cost of the solar thermal power plant varies with the size and the type. In this study, O\&M cost is assumed to be 0.25 USD cents per $\mathrm{kWh}[4,5]$. O\&M cost is mainly due to the replacement of the glass breakage and the cost of mirror washing including water cost. In the economic analysis, the insurance fees including O\&M cost is about $0.5 \%$ of the total annual income.

\subsection{Performance analysis}

According to the results obtained from the simulation of the solar thermal power plants by using SAM software [28], performance analysis is done by using its annual energy production, installation cost and plant capacity.

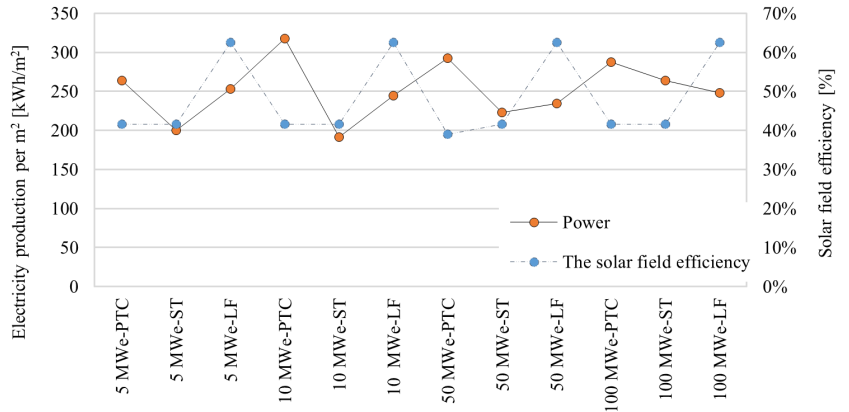

Figure 2. Electricity productions per unit area and solar field efficiencies of the solar thermal power plants.

The capacity of the selected CSP technologies is almost in the interval of $27.2 \%$ and $41.9 \%$ as shown in Figure 3. However, the lowest capacity is found for the technology LF with a value between 27.2 and $28.2 \%$. The overall efficiency for solar thermal power project using PTC is calculated for each size, it is found to be $11.58 \%$ for $5 \mathrm{MWe}-\mathrm{PTC}$ as a lower efficiency system, and $28.37 \%$ for $100 \mathrm{MWe}-\mathrm{LF}$ as the best value. In 
terms of power generation efficiency, $12.38 \%$ is obtained to be the highest value for $5 \mathrm{MWe}$ solar projects. Therefore, CSP project based on PTC technology can be considered as the best technology for small scale projects.

Figure 3 presents the worst scenario for $5 \mathrm{MWe}$ solar power project based on the ST technology. In the scenario, the specific efficiency is a few times lower than the ratio between a total installed cost per yearly energy generated in kWh of the studied project which leads to a long-term payback period.

Also, as seen in Figure 3, the best scenario is for both 50 MWe and 100 MWe project using PTCs. Interval between the total investment and the solar field efficiency in Figure 3 remains quietly constant when the size of the solar thermal power plant using LF technology increases while it decreases very fast with the increase of the plant size using ST technology.

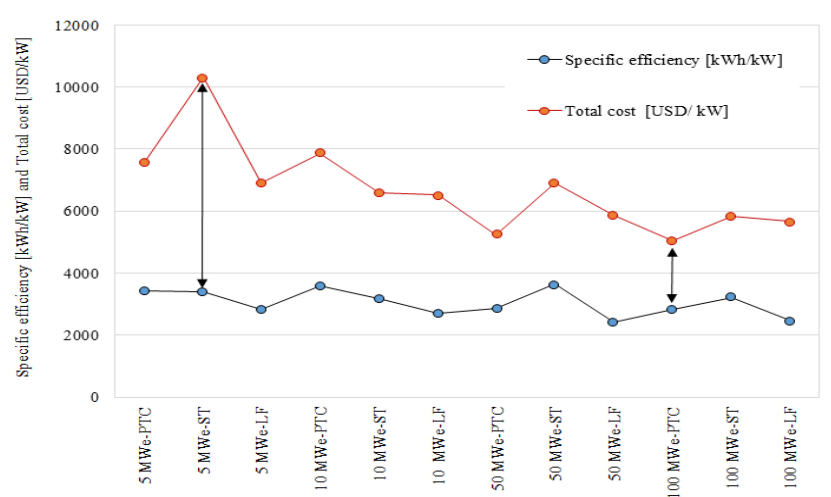

Figure 3. Total costs per kW and specific efficiencies of the solar thermal power plants.

According to the results shown in Figure 4, the investment cost of the CSP technologies is almost the same when the plant has around 10 MWe. However, the investment cost of the studied projects using linear Fresnel and parabolic collector technologies is generally low compared to using solar tower technology.

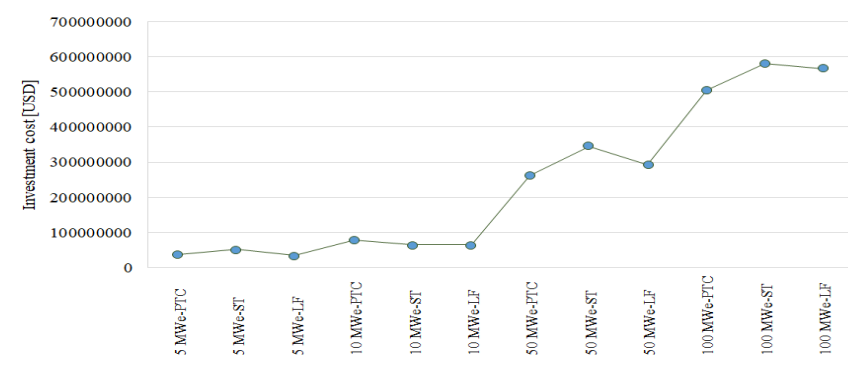

Figure 4. Investment costs for the solar thermal power plants.

Figure 5 presents annual energy production values from the solar thermal power plants. It can be said that annual energy productions are following the same profile of the investment cost presented in Figure 4, which clearly justifies the total installation cost per kW as presented in Figure 3. CSP-LF projects have the lowest initial investments while annual energy production values are less compared to the other technologies.

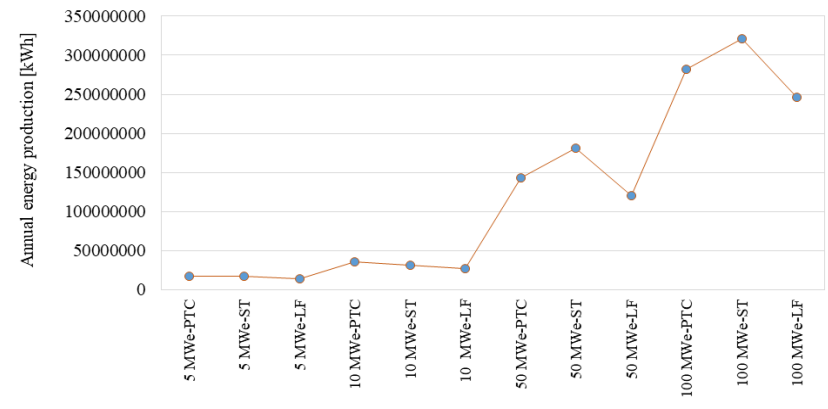

Figure 5. Comparative analysis of annual energy production values from the solar thermal power plants.

\subsection{Economic analysis}

Figure 6 shows the internal rate of return (IRR) values for the solar thermal power plants with various capacities. The value of IRR is higher than the discount rate. The lowest value is found to be $8.48 \%$ for 5 MWe plant using ST technology. The value of IRR is between $8.48 \%$ and $12.86 \%$ for the solar thermal power plants without CER/TAX. It is seen from Figure 6 that 10 MWe-ST has the highest value of IRR with CER/TAX application. The value of IRR is between 9.7\% and $14.36 \%$ when CER/TAX is applied for good energy production.

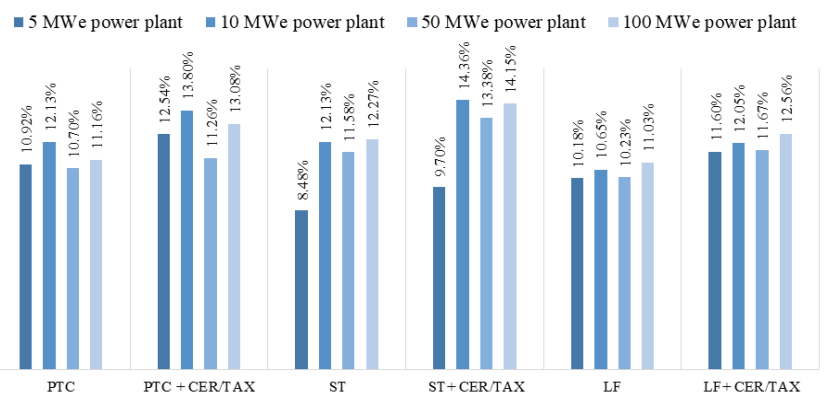

Figure 6. Internal rate of return analysis of the solar thermal power plants

The value of bonus carbon is assumed to be 3.14 USDcents/ $\mathrm{kWh}$ based on the technical data of each technology presented in Table 2. FiT, IRR and the size of the solar projects are determining factors which allow the project to be financed. The solar thermal power plants of 5 MWe and 10 MWe with FiT price of $27 \mathrm{USD} / \mathrm{kWh}$ have IRR values between $12.05 \%$ and $14.36 \%$. The solar thermal power plants of $50 \mathrm{MWe}$ and 100 MWe with FiT price of 21 USDcents/kWh (without any carbon pricing) have IRR values between $11.03 \%$ and $14.15 \%$. It is important to note that the selection of locations will affect considerably on annual energy production.

\subsubsection{Levelized Cost of Energy}

Levelized cost of energy (LCOE) contributes to the estimation of FiT price. Then, we can process for the determination of other key parameters necessary for the economic evaluation. Considering the values obtained during the financial simulation of these projects, we can determine the relationship between LCOE and FiT according to the size and technical specifications of the used CSP technologies. Thus, the technical and financial parameters have been used to carry out this information able to optimize the main values of the 
techno-economic analysis. According to the values such as payback period, IRR and LCOE found in the techno-economic analysis, FiT of the solar thermal power plant projects can be revised. In Figure 7, LCOE values and estimated FiT price are presented for CSP technologies with various capacities.

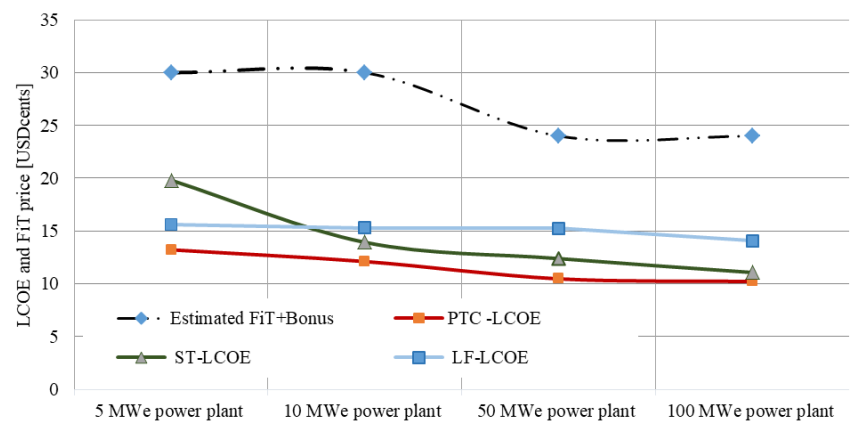

Figure 7. FiT price and LCOE values of the solar thermal power plants.

For this purpose, it is seen certain regularity on the LCOE evolution curve of LF technology. This regularity of the curve is almost perfect for sizes between 5 MWe-50 MWe while an inconstancy of the regularity is noticed for the other technologies. This irregularity is more important for the ST technology, particularly for the plant size between 5 and 10 MWe. PTC technology has a low value of LCOE compared to the other technologies with the range from 10.22 USDcents/kWh to 13.22 USDcents/kWh. Furthermore, this technology has a significant irregularity between 10 MWe and 50 MWe. Considering the results of some other studies in the literature, LCOE remains acceptable when it is slightly higher than half of FiT proposed by a regulatory agency of electricity or others governmental institutions. Otherwise, the value of FiT has to be decreased as mentioned above. This study shows that the different fixed FiTs are very well applicable to the use of PTC technology compared to the others. In addition, this value could be revised when the project receives any support to promote the use of CSP technologies for good in the sub-Saharan region.

\subsubsection{Payback Period}

The economic analysis of solar thermal power plant projects without carbon pricing approach presents the longest payback period with some irregularity. It can be noted that there is a great irregularity on the curve of the payback period evolution for solar projects with sizes between $5 \mathrm{MWe}$ and $10 \mathrm{MWe}$, while it has a better regularity for those with 50 MWe. Unlike the previous analysis, the conclusion cannot be extended to projects with the range between $50 \mathrm{MWe}$ and $100 \mathrm{MWe}$. In this case, the difference is much smaller and the irregularity of the curves remains proportional. Figure 8 shows the payback periods of CSP projects with the capacity between 5 MWe and 100 MWe.

ST technology has IRR of about $10 \%$ while the other technologies remain well above this value. In addition, optimal parameters have been found for project with the capacity of 50 MWe. CSP projects with the capacity above 50 MWe ba- sed on ST technology has the highest IRR followed by PTC technology independently to the application of carbon pricing approach. LCOE for these projects is leading by CSP projects using PTC technology and followed by ST technology for the size below $100 \mathrm{MWe}$. For solar project equal or above 100 MWe, ST technology presents better LCOE values compared to the other technologies. Also, it can be said that ST and PTC technologies are mature and appropriated technologies for large scale projects as seen in Figure 8.

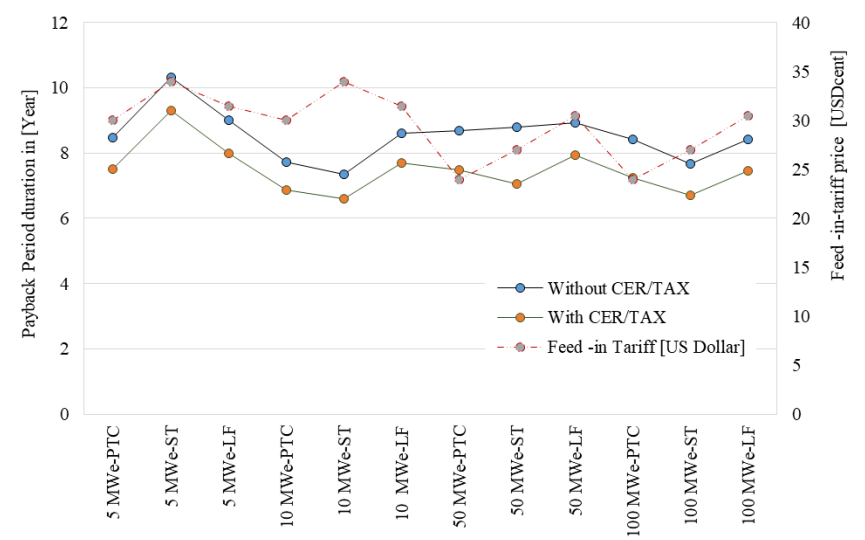

Figure 8. Payback periods with/without CER/TAX and FiT price of the solar thermal power plants.

\section{CONCLUSION}

In conclusion, the findings from the techno-economic analysis of the studied CSP technologies according to technical and financial parameters such as the size, location, carbon pricing application and environmental considerations can be can be summarized as below:

- The application of the raised principles of analysis has led to obtaining a large margin of FiT between 4 USDcents/kWh and 6 USDcents/kWh for each technology in the study that could help the negotiation issues for IPP companies.

- The determination of a carbon pricing impacts on the levelized cost of energy and consequently on FiT negotiation.

- LCOE able to match with the estimated FiTs of solar project less than $10 \mathrm{MWe}$ is LF technology.

- LCOE able to match with the estimated FiTs of solar projects above 50MWe is ST technology.

- PTC is the only technology which can be used for all capacities, and achieves the bankability aspect of the CSP project even without carbon bonus application.

These measures may vary according to public incentives determined by the energy policy of the countries such as the land leasing fees of charge, tax exemptions for the electricity transportation and distribution during a specific period of the day, application of the carbon pricing approach as the bonus for good production, and tax exoneration for the equipment during the construction phase. Moreover, the carbon pricing approach contributes to clean and sustainable energy generation taking into account environmental issues. 


\section{REFERENCES}

[1] International Renewable Energy Agency (IRENA) (2012). Renewable Energy Technologies: Cost Analysis Series, Concentrating Solar Power. Bonn, Germany.

[2] International Renewable Energy Agency (IRENA) (2013). Renewable Power Generation Costs in 2012: An Overview. Bonn, Germany.

[3] International Renewable Energy Agency (IRENA) (2015). Renewable Power Generation Costs in 2014. Bonn, Germany.

[4] International Renewable Energy Agency (IRENA) (2018). Renewable Power Generation Costs in 2017. Abu Dhabi, United Arab Emirates.

[5] International Renewable Energy Agency (IRENA) (2018). Renewable Capacity Statistics 2018. Abu Dhabi, United Arab Emirates.

[6] Shanghai Electric and CSP Focus (2019). Introduction of Dubai 950MW CSP+PV Project by Shanghai Electric. Dubai, UAE.

[7] Yeşilata, B. (2018). National Survey Report of PV Power Applications in Turkey 2018. IEA PVPS, http://iea-pvps.org/index.php?id=93.

[8] Moore, J. and Apt, J. (2013). Can hybrid solar-fossil power plants mitigate CO2 at a lower cost than PV or CSP? Environmental Science \& Technology, 47 (6): 2487-2493, DOI: 10.1021/es3021099.

[9] Calise, F., Accadia, M. D., Macaluso, A. A., Piacentino, A. and Vanoli, L. (2016). Exergetic and exergoeconomic analysis of a novel hybrid solar-geothermal polygeneration system producing energy and water. Energy Conversion and Management, 115: 200-220, DOI:10.1016/j.enconman.2016.02.029.

[10] Bonyadi, N., Johnson, E. and Baker, D. (2018). Techno-economic and energy analysis of a solar-geothermal hybrid electric power plant using a novel combined cycle. Energy Conversion and Management, 156: 542-554, DOI: 10.1016/j.enconman.2017.11.052.

[11] Beerbaum, S., and Weinrebe, G.,(2000). Solar thermal power generation in India a techno-economic analysis. Renewable Energy, 21 (2): 153-174. DOl:10.1016/S0960-1481(00)00006-9.

[12] Silva, R., Berenguel, M., Pérez, M. and Fernández-Garcia, A. (2014), Thermo-economic design optimization of parabolic trough solar plants for industrial process heat applications with memetic algorithms. Applied Energy, 113: 603-614. DOI: 10.1016/j.apenergy.2013.08.017.

[13] Boukelia, T.E., Mecibah, M.S., Kumar, B.N. and Reddy, K.S. (2015) Optimization, selection and feasibility study of solar parabolic trough power plants for Algerian conditions. Energy Conversion Management, 101: 450-459. DOI: 10.1016/j.enconman.2015.05.067.

[14] Morin, G., Dersch, J., Platzer, W., Eck, M. and Häberle, A. (2012). Comparison of linear Fresnel and parabolic trough collector power plants. Solar Energy, 86 (1): 1-12. DOI: 10.1016/j.solener.2011.06.020.

[15] Nezammahalleh, H., Farhadi, F. and Tanhaemami, M. (2010). Conceptual design and techno-economic assessment of integrated solar combined cycle system with DSG technology. Solar Energy, 84 (9): 1696-1705. DOI: 10.1016/J.SOLENER.2010.05.007.

[16] Musi, R., Grange, B., Sgouridis, S., Guedez, R., Armstrong, P., Slocum, A. and Calvet, N. (2017). Techno-economic analysis of concentrated solar power plant in terms of levelized cost of electricity. AIP Conference Proceedings, 1850 (160018): 1-12. DOI: 10.1063/1.4984538.

[17] Kost, C., Shammugam, S., Jülch, V., Nguyen, H.T. and Schlegl, T. (Fraunhofer ISE, 2018). Levelized Cost of Electricity Renewable Energy Technologies. Freiburg, Germany.

[18] Del Río, P. and Kiefer, C.P. (2018). Analysis of the Drivers and Barriers to the Market Uptake of CSP in the EU. Madrid, Spain.
[19] Lipu, M.S.H. and Jamal, T. (2013). Techno-economic analysis of solar Concentrating power (CSP) in Bangladesh. International Journal of Advanced of Renewable Energy Research, 2 (5): 750-762.

[20] International Energy Agency (IEA) (2017). Energy Technology Perspectives 2017: Catalysing Energy Technology Transformations. OECD/IEA, DOl: 10.1787/energy_tech-2017-en.

[21] Philibert, C., Frankl, P. and Dobrotkova, Z. (2010). Technology Roadmaps: Concentrating Solar Power. OECD/IEA, Paris, France.

[22] Philibert, C. (2014). Technology Roadmaps: Solar Thermal Electricity. OECD/IEA, Paris, France.

[23] Purohit, I. and Prohit, P. (2010). Techno-economic evaluation of concentrating solar power generation in India. Energy Policy, 38 (6): 3015-3029. DOI:10.1016/j.enpol.2010.01.041.

[24] Viebahn, P., Kronshage, S., Trieb, F. and Lechon, Y. (2008). Final report on technical data, costs, and life cycle inventories of solar thermal power plants, Project no. 502687. Paris, France.

[25] Biboum, A. and Yilanci, A. (2019). Feasibility study of biomass power plants fired with maize and sorghum stalk in the Sub-Saharan region: a case for the northern part of Cameroon. European Mechanical Science, 3 (3): 102-111. DOI: 10.26701/ems.493188.

[26] Saaty, T.L. (1980). The Analytic Hierarchy Process: Planning, Priority Setting, Resource Allocation. New York, USA.

[27] Esmail, M.A., Mokheimer, E.M.A., Dabwan, Y.D., Habib, M.A., Said, S.A.M. and Al-Sulaiman, F.A. (2014). Techno-economic performance analysis of parabolic trough collector in Dhahran, Saudi Arabia. Energy Conversion and Management, 86: 622-633. DOI: 10.1016/j. enconman.2014.06.023

[28] SAM, 2017, System Advisor Model 17.9.5, National Renewable Energy Laboratory (NREL) software. 